\section{SYI’AH ITSNA ‘ASYARIYAH}

\section{Khairuddin}

Program Pascasarjana UIN Suska Riau

Email:kh4iruddin@yahoo.co.id

\section{Abstract}

Syiah Istna 'Asyariyah: The religious thoughts proposed Muslim thinkers since the middle age have been caused by same understanding, namely how is religious can be understood truly. In the second phase of the first hijriah, there were two significant developments in history of Islamic society. First, there was internal conflict in Islamic society. Second, there was the arrival of Persian. From these two developments, there were some questions on theology and imamah (leadership). Based on these questions, some Muslim thinkers proposed their answers based on true Islamic teaching. Each formulation emerged and developed as different thought. Historically, the presence of syiah itsna Asyariyah can be separated from the doctrines and its interpretations to some verses adopted to justify it after the mystery of Mubammad al-Muntazhar (al-Mahdi), or compared with Imam al-Ia'far al-Shadiq, or even with Ali bin Abu Thalib. In fact, some ideas proposed that Ali did not know about his special status as imam ma'shum. Based on bistorical sources, the rise of some Syiah doctrines was mainly due to political problem. But, in later development, the syiah is acknowledged as theological sect.

Keywords: Syiah, Sect, Doctrine, and Theology.

\section{Pendahuluan.}

Fakta sejarah, bahwa pemikiran-pemikiran keagamaan sebaga amal yang ditawarkan para pemikir muslim sejak abad pertengahan adalah lahir dari suatu keprihatinan yang serupa, yaitu bagaimana ajaran agama bisa dipahami umat secara benar. Seperti selalu diulangulang oleh para sejarawan bahwa pada paroh kedua abad pertama Hijriyah, telah terjadi dua perkembangan yang sangat signifikan dalam sejarah umat Islam. Pertama, kenyataan bahwa di kalangan umat terjadi konflik internal yang boleh jadi tidak pernah mereka inginkan, ketika itu satu kelompok bukan saja mengutuk kelompok lain, tapi telah
Al-Fikra: Jurnal Ilmiah Keislaman, Vol. 8, No. 2, Juli-Desember 2009

saling membunuh. Konflik yang tragis ini dikenal dengan sebutan fitnah kubra (cobaan besar). Perkembangan kedua, masuknya bangsa Parsi dan sekitarnya berikut pemikiran dan keyakinan-keyakinan lamanya yang sudah terbentuk kuat dalam benak mereka masingmasing.

Dari kedua perkembangan tersebut muncullah pertanyaanpertanyaan teologis dan imamah dalam Islam. Bagaimana hukumya seorang muslim membunuh muslim lainnya tanpa hak. Sejauhmana ikhtiar manusia dalam hal aktivitas-aktivitasnya. Apa balasan yang akan mereka peroleh di akhirat berkenaan dengan aktivitas-aktivitas tersebut, sorga ataukah neraka. Siapakah sebenarnya yang berhak untuk memimpin umat, keluarga Nabi-kah atau siapa saja yang kreadibilitas di antara umat Islam, dan masih banyak lagi pertanyaanpertanyaan yang muncul yang tidak begitu penting diungkapkan dalam tulisan ini.

Dari keprihatinan atas pertanyaan-pertanyaan yang muncul ketika itu, para pemikir muslim merasa ditantang untuk merumuskan jawaban-jawabannya sesuai dengan ajaran Islam yang benar. Meskipun disadari bahwa rumusan-rumusan tersebut akhirnya diwarnai oleh subyektifitas pemikir, karena disadari pula bahwa rumusan-rumusan tersebut hadir berdasarkan corak dan pendekatan yang berbeda. Masing-masing rumusan tersebut tumbuh dan berkembang sebagai aliran pemikiran yang berdiri sendiri. Akhirnya tersebutlah nama-nama Khawarij, Murji'ah, Syi'ah, Qadariyah, Jabariyah, Mu'tazilah, Asy'ariyah dan lain sebagainya.

Dalam tulisan singkat ini, penulis hanya membahas satu bagian dari pecahan sekte yang ada, yaitu Syi'ah Itsna 'Asyariyah yang berkonsentrasi pada doktrin-doktin dalam ajaran mereka serta menyinggung sedikit pengaruh sosial dan pemikiran masa lalu dan dewasa ini. Adapun kajian historisnya hanya merupakan jembatan metode pendekatan pemahaman terhadap doktrin-doktrin tersebut. Kiranya penyajian tulisan ini merupakan kontribusi pemikiran tentang Syi'ah Itsna 'Asariyah, selain juga merupakan wacana dasar untuk mendapatkan kontribusi pemikiran selanjutnya. 
Khairuddin, Syi'ah Itsna 'Asyariyah

\section{Pengertian dan Sejarah Syi’ah Itsna 'Asyariyah}

Kata Syi'ah merupakan kosa kata Arab yang secara ethimologi berarti "pengikut, kelompok atau golongan". ${ }^{1}$ Demikian pula Itsna 'Asyariyah merupakan bilangan dalam bahasa Arab Itsna 'Asyara yang dibubuhi huruf ya nisbah yang arti dasarnya dua belas. Berdasarkan pengertian secara ethimologi tersebut diketahui bahwa Syi'ah Itsna 'Asyariyah adalah suatu pengikut, golongan atau kelompok yang memiliki faham dua belas. Sedangkan menurut terminologi, pengertian Syi'ah Itsna 'Asyariyah dapat dirujuk ungkapan Ahmad Amin, yaitu merupakan golongan Syi'ah Imamiyah yang meyakini bahwa imam yang ma'sum itu ada dua belas orang. ${ }^{2}$

Berdasarkan pengertian, baik menurut ethimologi, maupun terminologi seperti dikemukakan di atas, diketahui Syi'ah Itsna 'Asyariyah merupakan bagian dari sekte Syi'ah Imamiyah ${ }^{3}$ yang meyakini imam yang ma'sum terbut ada dua belas orang. Adapun Imam yang dua belas itu adalah; Ali ibn Abu Thalib (w. 41 H / $661 \mathrm{M}$ ), Hasan ibn Ali ibn Abu Thalib (w. 49 H / 669 M ), Husein ibn Ali ibn Abu Thalib (w. $61 \mathrm{H} / 680 \mathrm{M}$ ), Ali ibn Husein Zainal Abidin (w. 94 H / 712 M ), Muhammad al-Baqir (w. 113 H / 713 M), Ja'far alShadiq (w. 146 H / 765 M ), Musa al-Kazim (w. 183 H / 799 M),

${ }^{1}$ Lihat; Imam 'Allamah Abu al-Fadl Jamal al-Din Muhammad ibn Mukram ibn Manzur al-Afriqiy al-Mishriy (selanjutnya ditulis Ibn Manzur), Lisan al-'Arab, (Beirut: Daar al-Fikr, 1990), cet. 1, jilid VIII, hlm. 189

${ }^{2}$ Ahmad Amin, Fajr al-Islam, (Cairo: Maktabah al-Nahdhah, 1975) cet. ke-11, hlm. 272

${ }^{3}$ Syi'ah Imamiyah adalah golongan-golongan yang meyakini bahwa Nabi Muhammad saw. telah menunjuk Ali ibn Abu Thalib sebagai imam (pemimpin) penggantinya dengan penunjukan yang jelas dan tegas. Berdasarkan hal tersebut, mereka tidak mengakui keabsahan kepemimpinan Abu Bakar al-Shiddiq, Umar ibn al-Khattab maupun Utsman ibn 'Affan. Dalam perkembangannya Syi'ah Imamiyah ini pecah menjadi beberapa golongan, yaitu; al-Baqiriyah, al-Ja'fariyah al-Waqifah, alNawnsiyah, al-Afthahiyah, al-Syumaitiyah, al-Ismailiyah al-Waqifah, al-Musawiyah, alMufadhdhaliyah dan al-Itsna 'Asyariyah, namun sekte yang terbesar adalah Itsna 'Asyariyablm. Lihat; Dewan Redaksi, Ensiklopedi Islam, Jakarta: PT. Ikhtiar Baru Van Hoeve, 1994), cet. ke-3, jilid V, hlm. 8
Al-Fikra: Jurnal Ilmiah Keislaman, Vol. 8, No. 2, Juli-Desember 2009

Ali al-Ridha (w. 203 H / 818 M ), Muhammad al-Jawad (w. $221 \mathrm{H}$ / $835 \mathrm{M}$ ), Ali al-Hadi (w. $254 \mathrm{H} / 868 \mathrm{M}$ ), Hasan al-Askari (w. $261 \mathrm{H}$ / 874 M ) dan Muhammad al-Muntazhar ( al-Mahdi) (ghaib. 265 H / $878 \mathrm{M}$ ).

Para penulis sejarah Islam, berbeda persepsi tentang kapan munculnya Syi'ah. Pendapat pertama, Syi'ah pada hakikatnya telah ada semenjak wafatnya Nabi saw, yaitu ketika adanya perebutan kekuasaan antara golongan Muhajirin dan Anshar di Balai Pertemuan Saqifah bani Sa'idah. Ketika itu muncul suara dari bani Hasyim dan sejumlah kecil Muhajirin yang menuntut kehalifahan bagi Ali ibn Abu Thalib. ${ }^{4}$ Ahmad Amin lebih merinci lagi bahwa di antara sahabat Nabi sendiri ada yang berpendapat bahwa yang lebih berhak menjadi Khalifah (imam) setelah Nabi wafat adalah Ali ibn Abu Thalib, karena Ali memiliki sifat-sifat terpuji, tidak pernah menyembah berhala (syirik), selain juga memiliki hubungan Nasab yang dekat dengan Nabi. Pendapat tersebut antara lain dikemukakan oleh Salman al-Farisiy, Abu dzar al-Ghiffari dan Miqdad ibn al-Aswad. ${ }^{5}$

Pendapat kedua, kelompok Syi'ah mencuat ke permukaan pada akhir dari kekhalifahan Utsman ibn Affan, yakni ketika terjadinya fitnah besar-besaran atas terbunuhnya Utsman ibn Affan. ${ }^{6}$ Ketika itu kedok kesektean atau boleh juga disebut fanatisme kesukuan mencuat ke permukaan. Bani Hasyim berusaha untuk mengukuhkan Ali sebagai khalifah ke-empat sebagai pengganti Utsman ibn Affan, sehingga pembai'atan Ali sebagai khalifah tetap terwujud, meskipun tidak atas dasar suara bulat. Di pihak lain Bani Umaiyah berjuang atas nama Utsman ibn Affan menuntut kebijakan Ali agar berupaya mengusut

${ }^{4} I b i d$., hlm. 5, Bandingkan dengan Ibrahim Madkour, Aliran dan Teori Filsafat Islam, alih bahasa oleh Yudian Wahyudi Asmin, (Jakarta: Bumi Aksara, t.th.), hlm. 88

${ }^{5}$ Ahmad Amin, Dhuha al-Islam, (Cairo: Maktabah al-Nahdhah al-Mishriyah, t.th.) cet. ke-8, jilid III, hlm. 209

${ }^{6}$ Ibrahim Madkour, Aliran dan Teori.., hlm. 88 
Khairuddin, Syi'ah Itsna 'Asyariyah

tentang siapa pelaku dan apa motif pembunuhan Utsman. ${ }^{7}$ Dengan demikian, terlihat seolah-olah perjuangan mereka untuk kepentingan politik atas dasar kesektean semata. Melihat kenyataan tersebut, sejarawan muslim mengaitkannya dengan awal mula munculnya sekte Syi'ah.

Analisa sejarah ketiga, mencatat munculnya Syi'ah sebagai sekte dalam Islam setelah berakhirnya proses tahkim (arbitrase) antara simpatisan Muawiyah ibn Abu Sofyan dengan simpatisan Ali ibn Abu Thalib. 8 Sebagai akibat peperangan di Shiffin dan kegagalan serta kekecewaan yang dirasakan setelah adanya proses tahkim tersebut. Dari barisan Ali ibn Abu Thalib pecah menjadi dua kelompok besar dalam Islam. Pertama, kelompok yang tetap setia dengan Ali ibn Abu Thalib dan berusaha berjuang atas nama keluarga nabi. Mereka ini lazim disebut syi'atu Ali. Kedua, kelompok yang kecewa atas kebijakan tahkim yang akhirnya keluar dari barisan Ali serta memandang Ali dan Mu'awiyah sebagai orang yang tidak eksis lagi dengan ajaran Islam, sehingga mereka memandang keduanya sebagai kafir. Kelompok pertama yang tetap setia dengan Ali kemudian disebut dengan golongan Syi'ah. Sementara kelompok kedua yang menyatakan diri keluar dari kelompok Ali serta mengadakan pembrontakanpembrontakan untuk mengejar Mu'awiyah ibn Abu Sofyan dan Ali ibn Abu Thalib, sampai akhirnya Ali terbunuh di tangan Abdurrahman ibn Muljam tanggal 4 Januari 661 M bertepatan dengan tanggal 17

${ }^{7}$ Shaban, Islamic Histori (600-750 M) A New Interpretation, alih bahasa oleh Machnun Husein, (Jakarta: Rajawali Perss, 1993), cet. ke-1, hlm.111

${ }^{8}$ Ungkapan tersebut dapat dilihat dalam, Ibrahim Madkour, Aliran dan Teori..., hlm. 89, bandingkan juga dengan, Ensiklopedi Hukum Islam, hlm. 8 di sini bahkan dikemukakan bahwa pendapat yang ke-tiga ini dianggap sebagai pendapat yang paling populer.
Al-Fikra: Jurnal Ilmiah Keislaman, Vol. 8, No. 2, Juli-Desember 2009

Ramadhan tahun 40 H. ${ }^{9}$ Golongan inilah yang lazimnya disebut sebagaii sekte Khawarij. ${ }^{10}$

Bila dilihat pemikiran sejarawan yang berkembang tentang lahirnya syi'ah sebagai sekte dalam Islam, kiranya tiga pendapat tersebut dapat dilihat dari latar belakang pemikirannya. Pendapat pertama bisa kita terima bila yang dimaksud munculnya kosa kata Syi'ah. ${ }^{11}$ Sebab bila dimaksud sebagai sekte, kenyataannya, Nabi Muhammad saw. sendiri tidak pernah memberikan angin segar kepada keluarganya untuk menggantikan beliau setelah wafat. Selain itu juga bisa dilihat pernyataan Ali tentang hal ini, bahwa hakikatnya Ali tidak pernah berniat untuk merebut kekhalifahan setelah Nabi wafat, bahkan ia pernah mengatakan ketika ia ditanya orang setelah pulang dari membezuk Nabi Muhammad sakit yang akhirnya sebagai sebab beliau meninggal dunia, "demi Allah sesungguhnya aku tidak pernah berniat meminta jabatan tersebut". ${ }^{12}$

Bila dilihat lagi pendapat kedua yang mengatakan munculnya sekte Syi'ah ketika terjadinya fitnah kubra, juga bisa dibenarkan bila yang dimaksud hanya sebagai simpatisan semata, karena pada hakikatnya simpatisan Ali ibn Abu Thalib tersebut juga telah muncul semenjak wafatnya Nabi seperti yang telah dikemukakan di atas. Namun bila bila dikaitkan dengan Syi'ah sebagai sekte, tentu belum dapat dibenarkan, karena pada masa tersebut pembelaan atas nama Ali, meskipun sedikit diwarnai kecenderungan politik, namun penilaian mereka masih objektif yakni karena kreadibilitas yang

${ }^{9}$ Lihat Ibn Atsir, Al-Kamil fi al-Tarikh, (Beirut: Daar al-Fikr, 1979), jilid III, hlm. 387

${ }^{10}$ Masdar F. Mas'udi, Tela'ah Kritis Atas Theologi Mu'tazilah, dalam Budhy Munawwar Rachman (ed), Kontektualisasi Doktrin Islam Dalam Sejarah, Jakarta: Yayasan Paramadina, 1994), cet. ke-1, hlm. 125

${ }^{11}$ Kata Syi'ah sebagaimana dijumpai dalam al-Qur'an menunjukkan arti golongan; Dan sesunggubnya Ibrabim benar-benar termasuk golongannya (Nub). QS. AshShaffaat, ayat 83, Lihat Departemen Agama (Yayasan Penterjemah al-Qur'an), AlQur'an dan Terjemahnya, (Semarang: Toha Putra, 1989), hlm. 723

${ }^{12}$ Ahmad Amin, Fajr al-Islam., hlm. 266 
Khairuddin, Syi'ab Itsna 'Asyariyah

dimiliki Ali ibn Abu Thalib. Seperti Ali tidak pernah terlibat dosa syirik seperti menyembah berhala, ia orang pertama masuk Islam, banyak menghadapi bencana dan berjuang fi sabilillah serta memiliki nasab yang dekat dengan Nabi. ${ }^{13}$

Pemikiran ketiga tentang munculnya Syi'ah sebagai sekte dalam Islam, paling banyak ditulis oleh sejarawan. Pada masa setelah kegagalan dalam tahkim, bermunculan-lah pernyataan-pernyataan yang mendukung Ali ibn Abu Thalib. Pernyataan-pernyataan tersebut bukan hanya dalam wacana pemikiran semata, tetapi mereka juga berusaha menafsirkan beberapa nash al-Qur'an untuk mendukung pernyataan mereka. ${ }^{14}$ Juga berkembang pemikiran tentang kepemimpinan dalam Islam itu merupakan kewarisan yang harus diterima oleh keluarga Nabi. ${ }^{15}$ Selain itu, mereka juga berpendapat sebenarnya Nabi Muhammad saw. telah mewasiatkan kepemimpinan ummat kepada Ali ibn Abu Thalib setelah beliau wafat. ${ }^{16}$ Dengan demikian, kepemimpinan Abu Bakar al-siddieq ibn Abu Quhafah, Umar al-Faruq ibn al-Khattab dan Utsman zu al-nurain ibn Affan tidak mereka akui. Bahkan menurut Syi'ah, mereka itu merampas hak Ali ibn Abu Thalib. ${ }^{17}$ Selain itu, kepemimpinan (imamah) setelah Ali tersebut dijabat oleh keturunannya secara berurutan berdasarkan wasiat. $^{18}$

Bila difokuskan pada sejarah Syi'ah Itsna 'Asyariyah, sekte ini muncul setelah wafatnya imam ke-enam, yaitu Abu Abdullah Ja’far al-

${ }^{13}$ Ahmad Amin, Zhubr al-Islam, (Beirut: Daar al-Fikr, 1969), jilid IV, cet.ke-5, hlm. 111, juga bisa dibandingkan dengan tulisan Ibrahim Madkour, Aliran dan Teori..., hlm. 89

${ }^{14} \mathrm{Hal}$ ini dapat dilihat, mereka menafsirkan ayat 59 surat al-Nisa', yang dimaksud ulil Amri (pemimpin) dalam ayat tersebut menurut mereka adalah Ali ibn Abu Thalib. Penjelasan ini bisa dilihat; Ahmad Amin, Zhubr al-Islam., hlm. 113

${ }^{15}$ Ahmad Amin, Fajr al-Islam, hlm. 266

${ }^{16}$ Ibid., hlm. 267

${ }^{17}$ Joesoef Sou'yb, Pertumbuban dan Perkembangan Aliran-aliran Sekta Syi'ah, (Jakarta: Pustaka al-Husna, 1982), hlm. 14

${ }^{18}$ Ahmad Amin, Dhuba al-Islam, hlm. 212
Al-Fikra: Jurnal Ilmiah Keislaman, Vol. 8, No. 2, Juli-Desember 2009

Shadiq (w. 148 H / 766 M ) yang wafat di Madinah al-Munawwarah dan dimakamkan pada perkuburan Baqi'. Ja'far al-Shadiq punya beberapa orang putra dengan urutan usia sebagai berikut; Ismail ibn Ja'far, Musa ibn Ja'far, Abdullah ibn Ja'far, Ishaq ibn Ja'far dan Muhammad ibn Ja'far. Ismail ibn Ja'far sebagai putra tertua dari Imam Ja'far al-Shadiq meninggal lebih duluan dari bapaknya. Dengan demikian, maka jabatan Imam berpindah kepada adiknya Musa ibn Ja'far yang diberi gelar dengan al-Kazim. Golongan Syi'ah yang berpendapat Jabatan Imam berpindah pada Musa al-Kazim dan seterusya pada keturunannya sampai pada Imam yang ke dua belas inilah yang kemudian disebut dengan Syi'ah Itsna 'Asyariyah. ${ }^{19}$ Sedangkan golongan yang berpendapat Jabatan Imam setelah Ja'far alShadiq tetap berpindah kepada Ismail ibn Ja'far, mereka inilah yang disebut dengan Syi'ah Ismailiyah atau lazim juga disebut Si'ah Syab'iyah. ${ }^{20}$

\section{Doktrin Syi'ah Itsna 'Asyariyah.}

Syi'ah Itsna 'Asyariyah yang mengakui adanya dua belas Imam yang ma'shum menganut lima doktrin yang paling pokok, yaitu; Imamah, Ishmah, Mahdiyah, Raj'ah dah Taqiyah.

\section{Imamah.}

Dalam aliran Imamiyah, pembahasan tentang Imamah masih terbatas pada pembahasan tentang siapa yang berhak memegang kekuasaan tertinggi dalam dunia Islam, sedangkan dalam aliran Syi'ah Itsna 'Asyariyah yang juga merupakan bagian Imamiyah memperoleh penafsiran lebih lanjut.

${ }^{19}$ Joesoef Sou'yb, Pertumbuhan dan Perkembangan..., hlm. 36

${ }^{20}$ Tentang munculnya sekte Syi'ah Itsna 'Asyariyah dan Ismailiyah ini dapat dilihat tulisan Azim Nanji, Syi'ah Ismailiyah, dalam Jurnal Ulumul Qur'an, Nomor 4, Vol. VI, thlm. 1995, hlm. 28 
Khairuddin, Syi'ab Itsna 'Asyariyab

Al-Kullaini ${ }^{21}$ menyebutkan, Imam itu mempunyai hubungan rohaniah dengan Allah sebagaimana halnya para Nabi dan Rasul. Adapun perbedaannya, dalam menerima wahyu yang disampaikan Jibril, Rasul dapat melihat dan mendengar pembicaraannya. Nabi, kadang dapat mendengar tapi tidak bisa melihat atau kadang dapat melihat tapi tidak bisa mendengar pembicaraannya. Sedangkan Imam hanya mampu mendengar tapi tidak bisa melihat Jibril.

Mengakui Imam merupakan rukun Iman. ${ }^{22}$ Pendapat ini disandarkan kepada ungkapan Abu Ja'far, ${ }^{23}$ "seseorang baru dikatakan berbakti kepada Allah apabila ia mengenali Allah". Mengenali Allah dengan beriman kepada-Nya, kepada Rasul-Nya dan juga kepada para Imam-Nya. Dengan demikian, maka mengenali Allah adalah dengan cara berlindung kepada Allah dari segala musuh Imam. Abu Ja'far

${ }^{21}$ Al-Kullaini adalah Muhammad ibn Ya'kub al-Kullaini (w. 328 H / 939 M). Merupakan tokoh Syi'ah dan penulis Kitab al-Kafi, terdiri dari tiga jilid. Jilid pertama berisikan pokok-pokok keyakinan. Jilid kedua dan ketiga berisi ketentuanketentuan hukum. Dalam bukunya tersebut terdapat 16.000 buah hadis yang sanadsanadnya melalui jalur tokoh-tokoh yang dimuliakan Syi'ahlm. Ia sangat dimuliakan tokoh Syi'ah sebagaimana layaknya Imam Bukhari di kalangan Sunni. Ahmad Amin, Dhuha al-Islam, hlm. 215

${ }^{22}$ Penjelasan tentang pengakuan kedua belas Imam sebagai pemimpinpemimpin umat, dapat dilihat ulasan Syarafuddin al-Musawi ketika menjelaskan makna Islam dan Iman. Berdasarkan pemahaman terhadap ayat 14 surat al-Hujurat tentang ungkapan orang-orang Arab Badui "kami telah beriman". Katakanlah (kepada mereka) kamu belum beriman, tetapi katakanlah kami telah Islam. Dipahami sesungguhnya yang dimaksud dengan Islam itu hanya merupakan pernyataan masuk agama dan berserah diri pada Nabi Muhammad saw. Adapun Iman merupakan keyakinan yang teguh dalam hati sanubari kaum beriman seraya mengikrarkannya dengan lisan. Dengan demikian Iman lebih khusus dari Islam. Adapun kami (kaum Syi'ah) jelas Syarafuddin al-Musawi, menambah satu hal lagi, yakni wilayah (pengakuan keduabelas Imam sebagai pemimpin-pemimpin umat) Sayyid Abdul Husain Syarafuddin al-Musawi, Al-Fushul al-Mubimmat fi Ta'lif alUmmah, alih bahasa oleh Mukhlis, (Bandung: Mizan: 1991), cet. ke-2, hlm. 21

${ }^{23}$ Yang dimaksud Ja'far disini adalah Abu Ja'far Muhammad ibn 'Ali yang diberi gelar al-Jawwad, merupakan Imam IX dalam sekte Syi'ah Itsna 'Asyariyah.
Al-Fikra: Jurnal Ilmiah Keislaman, Vol. 8, No. 2, Juli-Desember 2009

selanjutnya menjelaskan umat tanpa Imam akan menjadi umat yang sesat dan apabila mati dalam keadaan demikian, maka mati dalam keadaan kufur dan nifaq. Hal ini mereka tafsirkan dari al-qur'an, surat al-An'am ayat 122 dan an-Namal 89.

Imam merupakan penuntun dan wali-wali Allah dan perbendaharaan ilmu-Nya yang dapat menafsirkan wahyu dan merupakan alam terkuat (bujjat al-balighah) bagi setiap yang berada di bawah langit dan di permukaan bumi, Imam itu diberikan pengetahuan tentang hari kiamat dan ia juga mengetahui keadaan manusia. ${ }^{24} \mathrm{Hal}$ ini mereka tafsirkan dari surat al-Ra'd ayat 7

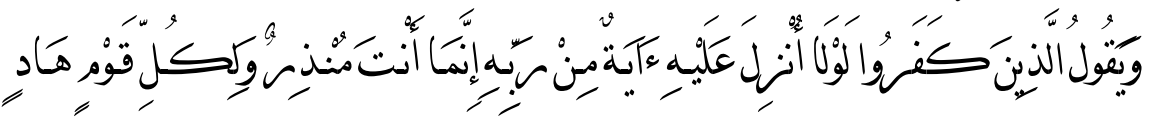

Imam merupakan nur Allah (al-Taghabun; 8) dan nur Imam dalam kalbu setiap mukmin yang lebih terang dari cahaya matahari di siang hari. Apabila Allah menutup nur Imam dalam hati seseorang, maka hatinya akan tertutup dan gelap gulita.

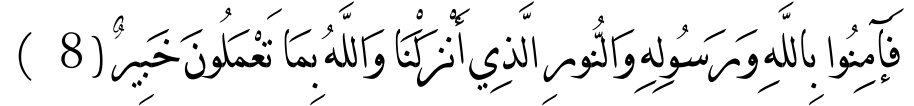

Penafsiran imam seperti inilah menimbulkan pengkultusan terhadap Ali dan keturunannya. Konsepsi ini pula-lah yang merembet pada pengkultusan para sayyid dan sayyidah, syarif dan syarifah yang muncul dalam kehidupan masyarakat muslim belakangan karena dinyatakan sebagai turunan Ali, Hasan dan Husein. ${ }^{25}$

Bila dilihat penafsiran seperti ini, merupakan penafsiran yang dikemukakan oleh Muhammad ibn Ya'kub al-Kullaini yang hidup pada pertengahan abad ke-4 Hijriah. Sedangkan Abu Ja'far al-Shadiq wafat pada pertengahan abad ke-2 Hijriah dan Abu Ja'far Muhammad

${ }^{24} \mathrm{Abu}$ al-Fath Muhammad Abd al-Karim ibn Abu Bakar Ahmad alSyahrastani, Al-Milal wa al-Nihal, (Beirut: Daar al-Fikr, t.th), hlm. 173

${ }^{25}$ Joesoef Sou'yb, Pertumbuhan dan Perkembangan..., hlm. 44 
Khairuddin, Syi'ah Itsna 'Asyariyah

al-Jawwad wafat di penghujung abad ke-2. Dengan demikian,maka jarak hidup mereka berkisar 150-200 tahun. ${ }^{26}$

Jika dilihat potret kehidupan Abu Abdillah Ja'far al-Shadiq (w. $148 \mathrm{H}$ ), ia adalah seorang ulama yang sangat wara', taat dan tidak mau melibatkan dirinya dalam kancah perpolitikan, sehingga ia wafat dengan tenang di Madinah al-Munawwarah dan dimakamkan di pemakaman Baqi'. Bahkan dua orang Imam pendiri mazhab sunni, Imam Abu Hanifah dan Imam Malik ibn Anas yang terkemuka sampai saat ini tetap dikenal orang pernah belajar dengan Ja'far al-Shadiq. ${ }^{27}$

\section{Ishmah.}

'Ismah merupakan bahasa Arab yang berarti keterpeliharaan. Adapun yang dimaksud dengan Tsmah dalam kajian ini adalah salah satu doktrin Syi'ah Itsna 'Asyariyah yang menyatakan bahwa para Imam itu terpelihara dalam seluruh kehidupannya. Tidak pernah melakukan dosa kecil apalagi dosa besar. Tidak pernah melakukan kema'shiatan sedikitpun dan terpelihara dari setiap kesalahan maupun kelupaan.

Dalam sekte Ismailiyah, penafsiran 'Ishmah ini lebih jauh lagi, yakni apabila ternyata seorang imam melakukan sesuatu hal yang menurut orang awam merupakan kemungkaran dan ma'shiat, maka menurut mereka bukan sebagai munkarat dan ma'shiyat di sisi Allah. Hal ini karena Imam itu pada hakekatnya sudah bebas dari taklif syari'at karena sudah sampai pada maqam ma'rifat.

Doktrin 'Ishmat (infalibility) tersebut juga terdapat dalam Greja Katolik Roma yang berasal dari Injil Yahya, 14; 16 dan telah menjadi anutan semenjak abad-abad permulaan. Hal ini lebih dipokuskan pada diri pribadi Paus yang berkedudukan di Vatikan. Kemudian memperoleh rumusan yang lebih konkrit dalam Konsili Vatikan I (1866-1870) dan selanjutnya dalam Konsili Vatikan II (1962-1965).

\section{${ }^{26}$ Ibid.}

${ }^{27}$ Moenawar Chalil, Biografi Empat Serangkai Imam Mazhab, Jakarta: Bulan Bintang, 1990), cet. ke-7, hlm. 87
Al-Fikra: Jurnal Ilmiah Keislaman, Vol. 8, No. 2, Juli-Desember 2009

Menurut Joesoef Sou'yb bolah jadi faham infalibility Katolik ini yang menyslusup dalam faham sebagian muslim ketika peradaban muslim berhadapan dengan peradaban Barat, bahkan dalam Muslim Syi'ah doktrin ini lebih ekstrim lagi. 28

Bila dilihat pada pribadi para Nabi sendiri lewat petunjuk alQur'an, Adam dinyatakan berbuat dosa, tapi ia bertaubat (al-Baqarah; 35-37). Nabi Musa telah berdosa karena membunuh seseorang, namun ia bertaubat (al-Qashash; (14 -19). Nabi Daud pernah berbuat kesalahan besar, tapi ia bertaubat (Shad; 17-25). Bahkan Nabi Muhammad dinyatakan bingung sebelum menjabat risalah, namun Allah berikan bimbingan (ad-Dhuha; 6-8) dan pribadi Nabi Muhammad disebutkan sebagai manusia biasa, namun dibimbing wahyu (al-Kahfi; 111).

\section{Mahdiyah.}

Mahdiyah merupakan salah satu doktrin utama Syi'ah Dua Belas yang beranggapan bahwa Imam ke-12, Muhammad ibn Hasan al'Askari (gaib $260 \mathrm{H}$ ) yang diberi gelar Muhammad Mahdi alMuntazhar. Secara bahasa mahdi merupakan isim maful dari kata badaya yang berarti orang yang diberi bidayah (petunjuk). Namun menurut Ahmad Amin kata mabdi itu tidak pernah digunakan dalam al-Qur'an, tetapi yang dijumpai adalah kata mubtadiy. ${ }^{29}$

Kisah tentang Imam Mahdi tersebut dalam faham Syi'ah merupakan kisah yang sangat unik, mulai dari kelahirannya sampai keghaibannya dan juga saat ia muncul kembali. Dalam keyakinan Syi'ah, Imam Mahdi tersebut bersembunyi di sebuah goa yang terdapat di Surra Man Raa, Irak, semenjak lebih dari seribu tahun lebih dan mungkin akan berlanjut beribu tahun lagi sampai saat

\footnotetext{
${ }^{28}$ Joesoef Sou'yb, Pertumbuhan dan Perkembangan..., hlm. 47

${ }^{29}$ Ahmad Amin, Dhuba' al-Islam, hlm. 235
} 
Khairuddin, Syi'ah Itsna 'Asyariyah

kemunculannya dengan membawa dan melaksanakan syari'atnya Nabi Daud. ${ }^{30}$

Ketika masa kegaibannya, ia berumur 5 tahun, ia juga membawa semua warisan yang berharga seperti; al-Qur'an sempurna yang ditulis oleh Ali, kitab-kitab samawi kuno, Taurat, Injil dan Zabur, shuhuf para Nabi lainnya dalam bentuk yang asli, mushhaf Fatimah, mu’jizat para Nabi; tongkat Nabi Musa, baju Adam, cincin Sulaiman dan lain sebagainya. Karena dunia harus ada Imam, dan kalau tidak ada Imam, maka dunia akan hancur, maka Imam akhir zaman harus tetap hidup sampai hari kiamat. Di saat ia muncul, maka ia akan memimpin dunia. ${ }^{31}$

Setelah kegaiban Imam Mahdi tersebut, kaum Syi'ah selalu menunggu dan berdo'a untuk kemunculannya " 'ajjalallabumma farajahu " ya Allah mudah-mudahan engkau segera memunculkannya. Dalam memimpin dunia ini, kadang-kadang Imam Mahdi ini berdialog dengan naib al-Imam yang tetap ada sepanjang masa melalui surat yang mereka kirimkan secara rahasia. Jawaban Imam akhir zaman tersebut berisi seluruh penomena sosial seperti masalah imamah dan juga pikiran-pikiran keagamaannya. Korespondensi tersebut kemudian dijadikan dalil-dalil figh Syi'ah yang dikenal dengan wilayat al-faqib. ${ }^{32}$

\section{Raj'ah.}

Raj'ah merupakan salah satu doktrin syi'ah Itsna 'Asyariyah sebagai pengembangan dari ajaran Mahdiyah. Raj'ah berasal dari kata raja’a yang berarti kembali. Dalam doktrin Syi'ah, diyakini sebagai suatu doktrin bahwa kelak semua manusia yang paling shaleh dan yang paling durhaka akan dihidupkan kembali bersamaan dengan dibangkitkannya Imam Mahdi. Hal ini mereka dasarkan pada alQur'an, surat Ghafir (Mukmin) ayat 11.

${ }^{30}$ Muhammad al-Hasyimi, 'Aqaid al-Syi'ah fi al-Mizan, alih bahasa oleh M.Rasyidi, (Jakarta: Bulan Bintang, 1989), hlm. 127

${ }^{31}$ Ibid., hlm. 128

${ }^{32}$ Ibid., hlm. 132
A1-Fikra: Jurnal Ilmiah Keislaman, Vol. 8, No. 2, Juli-Desember 2009

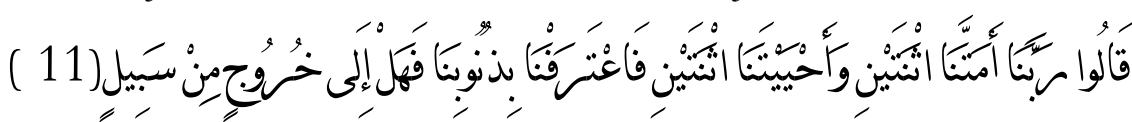

Artinya: "Mereka menjawab, ya Tuhan kami, Engkau telah mematikan kami dua kali dan telah menghidupkan kami dua kali, lalu kami mengakui dosa-dosa kami. Maka adakah suatu jalan bagi kami untuk keluar dari neraka ".

Menurut Syi'ah, dalam ayat tersebut, terdapat kata raj'ah yang menyebutkan adanya dua kehidupan setelah mati, yakni kehidupan di akhirat dan kehidupan sebelum di akhirat. Menurut mereka yang dimaksud dengan raj'ah itu adalah kehidupan sesudah mati sebelum di akhirat.

\section{Taqiyah.}

Taqiyah berasal dari kata taqiya atau ittaqa yang berarti takut. Pada awalnya, taqiyah ini merupakan doktrin politik dalam Syi'ah merupakan refleksi atas ketertindasan mereka dari kejaran lawan politik mereka pada masa dinasti Umaiyah dan Abbasiyah. Tetapi, akhirnya taqiyah ini diyakini sebagai doktrin agama yang merupakan sikap berhati-hati demi menjaga keselamatan jiwa karena khawatir bahaya yang dapat menimpa dirinya. Dalam hal ini terjadi sikap penyembunyian identitas dan berbuat atas ketidakterusterangan.

Selain yang telah disebutkan di atas, masih banyak lagi doktrin Syi'ah Itsna 'Asyariyah yang menurut Joesoef Sou'yb bukan merupakan doktrin pokok, seperti; Tawassul, merupakan permohonan sesuatu kepada Allah SWT dengan menyebutkan pribadi atau kedudukan seorang Nabi, Imam atau seorang wali supaya do'anya cepat dikabulkan oleh Allah SWT; Tawalli (mengangkat seseorang sebagai pemimpin), Tabarri (sikap menjauhkan diri dari seseorang); Marja'iyah atau Wilayat al-Faqih, (merupakan kepemimpinan fuqaha' dalam urusan agama maupun masyarakat setelah kegaiban imam kedua belas); Bada', (keyakinan bahwa Allah mampu mengubah suatu keputusan atau peraturan yang telah ditetapkan-Nya dengan keputusan atau ketetapan yang baru); 'Asyura (merupakan peringatan 
Khairuddin, Syi'ah Itsna 'Asyariyah

dan hari berkabung atas wafatnya Husein bin Ali dan keluarganya di tangan pasukan Yazid bin Muawiyah yang dilaksanakan pada tanggal 10 Muharram).

Dalam sekte Syi'ah Itsna 'Asyariyah tercatat nama Hisyam ibn alHakam (w. 198 H/814 M) sebagai Teolog yang cenderung men-tajsim dan tasybih (meng-antropomorfis-kan) Allah. Faham ini dianut untuk menentang kaum Mu'tazilah yang menolak teori Imamah versi Syi'ah yang akhirnya menimbulkan konflik berkepanjangan antara kedua kubu ini. Akhirnya atas prakarsa Bani Buaihi, kaum Si'ah Itsna 'Asyariyah menjadi dekat kembali dengan Mu'tazilah. Pada fase ini muncul teolog Syi'ah,antara lain Syekh al-Mufid (w. 413 H/1022M) dengan teori al-tanzih wa al-Tajrid (me-Maha Suci-kan dan me-Maha abstrakkan Allah). Pada periode berikutnya teologi Islam di tangan mereka bercampur dengan filsafat atas prakarsa Nasir al-Din al-Tusi (w. $673 \mathrm{H} / 1277 \mathrm{M}$ ), kemudian bercampur dengan Tasauf atas prakarsa Syekh al-Amali (w. 787 H/1387 M). ${ }^{33}$

Pada perkembangan berikutnya pemikiran Mu'tazilah diulangi kembali pada sekte Syi'ah Itsna 'Asyariyah, seperti sifat Allah adalah 'ain Zat (Zat Allah itu sendiri) dan al-Qur'an adalah makhluq. Sebaliknya mereka menolak teori al-Kalam al-Nafsi (sifat berbicara merupakan bagian dari zat), Allah bisa dilihat dengan pandangan mata baik di dunia maupun akhirat, mereka juga me-Maha Sucikan Allah dari perbuatan jelek. ${ }^{34}$

\section{Kesimpulan.}

Bila dilihat historis berdirinya sekte Syi'ah Itsna 'Asyariyah, maka diketahui munculnya doktrin-doktrin (selain Imamah) dan penafsiranpenafsiran terhadap beberapa ayat yang diadopsi untuk menjustifikasi ajaran yang mereka anut baru muncul beberapa lama setelah keghaiban imam Muhammad al-Muntazhar (al-Mahdi), apalagi bila dibandingkan dengan Imam Ja'far al-Shadiq dan lebih lagi bila

${ }^{33}$ Ibrahim Madkour, Aliran dan Teori..., hlm. 95

${ }^{34}$ Ibid.
Al-Fikra: Jurnal Ilmiah Keislaman, Vol. 8, No. 2, Juli-Desember 2009 dinisbahkan dengan Ali ibn Abu Thalib. Sehingga sering disampaikan bahwa Ali sesungguhnya tidak mengetahui tentang pengkultusan dirinya sebagai salah seorang Imam ma'shum.

Berdasarkan historis juga disadari lahirnya beberapa doktrin Syi'ah tersebut bermula dari persoalan politik. Namun pada perkembangan berikutnya menjadi sebuah ajaran yang diyakini kuat oleh pengikut Syi'ah sebagai suatu akidah.

\section{Bibliografi}

Amin, Ahmad, Dhuha' al-Islam Jilid III, (Cairo: Maktabat al-Nahdhah, t.th.).

Fajr al-Islam, (Cairo: Maktabat al-Nahdhah, 1975).

, Zhubr al-Islam Jilid IV, (Beirut: Daar al-Fikr, 1969).

Chalil, Moenawar, Biografi Empat Serangkai Imam Mazhab, (Jakarta: Bulan Bintang, 1990).

Dewan Redaksi, Ensiklopedi Islam Jilid V, (Jakarta: PT. Ikhtiar Baru Van Hoeve, 1994).

Hasyimi, Muhammad al-Kamil, 'Aqaid al-Syi'ah fi al Mizan, alih bahasa oleh M.Rasyidi (Jakarta: Bulan Bintang, 1989).

Ibn Atsir, Al-Kamil fi al-Tarikh, (Beirut: Daar al-Fikr, 1979).

Ibn Manzur al-Afriqy al-Mishry, Imam 'Allamah Abu al-Fadl Jamal alDin Muhammad ibn Mukram, Lisan al-'Arab Jilid VIII, (Beirut: Daar al-Fikr, 1990).

Madkour, Ibrahim, Aliran dan Teori Filsafat Islam, alih bahasa oleh Yudian Wahyudi Asmin, (Jakarta: Bumi Aksara, t.th.).

Mas'udi, Masdar F., Tela'ah Kritis Atas Teologi Mu'tazilah, dalam Budy Munawwar Rachman (ed), Kontekstualisasi Doketrin Islam Dalam Sejarah, (Jakarta: Yayasan Paramadina, 1994). 
Khairuddin, Syi'ab Itsna 'Asyariyah

Musawi, Sayyid Abdul Husein Syarafuddin, Al-Fushul al-Mubimmat fi Ta'lif al-Ummah, alih bahasa oleh Mukhlis, (Bandung: Mizan, 1991).

Nanji, 'Azhim, Syi'ah Ismailiyah, dalam Jurnal Ulumul Qur'an, Nomor 4, Vol. 6, tahun 1995.

Salus, Ali Ahmad, Ma'a al-Syi'ah al-Itsna 'Asyariyah fi al-Ushul wa al-Furu' (Dirasat Muqaranat fi al-Hadits wa 'Ulumub wa Kutubub), alih bahasa oleh Asmuni Solihan Zamakhsari, (Jakarta: Pustaka al-Kautsar, 2001).

Shaban, Islamic Histori (600-750) A New Interpration, alih bahasa oleh Machnun Husein, (Jakarta: Rajawali Pers, 1993).

Sou'yb, Joesoef, Pertumbuban dan Perkembangan Aliran-aliran Sekta Syi'ah, (Jakarta: Pustaka al-Husna, 1982). 